Stine Vik

https://doi.org/10.26881/pwe.2018.42.10

ORCID: 0000-0001-8382-4053

Inland Norway University of Applied Sciences

Stine.Vik@inn.no

Hege Merete Somby

ORCID: 0000-0001-5713-9239

Inland Norway University of Applied Sciences

hege.somby@inn.no

\title{
Defectology and inclusion
}

\begin{abstract}
Summary
In this article we claimed that the conception and rhetoric Vygotsky questioned in his works on Defectology still are relevant today in the age of inclusive education. The educational system in several western countries is built upon the strategy of reducing the gap between what the "normal" child can do and the expectations of the disabled child's competence and skills. The educational system is constructed to handle the "normal" child, and will make adjustments for the disabled child in relation to what the "normal" child is capable of. This is in conflict with the ideology of inclusive education. In our opinion, the educational strategy as a "negative education" is a paradox to the overarching aim of inclusive education. As long as we measure what the child is not able to do, we will not be working towards an inclusive education. In this article we make use of Vygotsky's perspectives on defectology and "positive differential approach" to discuss these issues.
\end{abstract}

Keywords: defectology, inclusive education, positive differential approach

\section{Introduction}

Vygotsky played a key role in establishing the discipline of Defectology in the USSR. Although the word defectology has no direct analogy to Western educational system, it roughly covers the term special education, and partly provides services to the same population as special education in Western countries (Davydov 1995; Gindis 1995: 78). Vygotsky's work on defectology has to a limited extent been spread in the West, but in fact defectology was the main empirical domain from which Vygotsky obtained data for his theoretical concepts, so a greater part of Vygotsky's scientific legacy is actually to be found within the area of defectology (Gindis 1995).

Although the term defectology may sound harsh to western pedagogues, Vygotsky's work within this field has surprisingly strong explanatory power on several issues on education even today. In this paper, we argue that the conception and rhetoric of pedagogy Vygotsky questioned almost a hundred years ago, still dominates the Western understanding of education for children with disabilities today. Even though Vygotsky's terms may be outdated, we will contend that the rhetoric is still visible and in conflict with the glob- 
al strive for inclusive education. Vygotsky stated that questions regarding children with disability were posed and solved as quantitative issues, continuously subtracting what is probable from what is expected. Our claim is that education still is based on quantitative measurements where children with disabilities are measured according to what we - the society - perceive as "normal". It is our belief that educational efforts are targeted towards the gap between what the disabled child is capable of and what the "normal" child is capable of, and that this assumption seldom is questioned. Vygotsky calls this a negative pedagogy. We will contend that this principle is irreconcilable with the efforts of inclusive education as it is advocated through the Salamanca Statement of 1994 (UNESCO 1994), an international marker for the debate and efforts for inclusive education. The Salamanca Statement is advocating diversity as a quality and the educational system as responsible for execution. Vygotsky's concern about a quantitative understanding and a negative pedagogy can point us in a direction for a more positive discussion of ability-approach. His suggestion was that education for children with special needs should start from a positive approach of the strengths of the child, a contention in line with the Salamanca statement.

\section{Defectology}

Vygotsky contributed to the understanding of development of children with special needs basically on two foundations; his general cultural-historical theory of human development (see Vygotsky 1998), and his special theory of disontogenesis (theory of distorted development). His theory of disontogenesis is founded upon two main premises 1: The distinction between primary and secondary defects, and 2: The interfunctional relationship in mental development (Kozulin \& Gindis 2007: 340). According to Vygotsky, there are primary defects referring to an actual biological problem, an impairment that influences the child's development of the natural functions, such as perceptions, memory and so forth. The secondary defect, on the other hand, refers to psychological difficulties acquired through the process of social interaction (Vygotsky 1995), the social implications of the biological defect. The interfunctional relationship between the primary and the secondary defects will influence the ability of the individual. With this latter theory, Vygotsky made a distinct distance to the common assumptions of his time that disability is mainly biological in nature (Kozulin \& Gindis 2007). He claimed that the problem of disability is not the biological disability itself, but its social implications.

Any physical handicap... not only alters the child's relationship with the world, but above all affects his interaction with people. Any organic defect is revealed as a social abnormality in behaviour. It goes without saying that blindness and deafness per se are biological factors; however, teachers must deal not so much with these biological factors by themselves, but rather their social consequences (Vygotsky 1993: 102).

This distinction of the two "types" of disability is very similar to the discourses on disabilities described as a medical model and the social model. The medical model examines 
and resolves disabilities as pathological issues, whereas the social model examines and resolves disabilities as relational issues (see below). In his theory, Vygotsky emphasizes the biological need to "fit in" with the society, as social interactions are necessary for human development.

Vygotsky's difficulty approach is somewhat narrow, but his emphasis is that a difficulty may be regarded as a social or systemic problem rather that the child's biological problem. One can understand this as pure compensating strategy thinking, but his emphasis on social issues points to an approach whereby difficulties are rather a problem for the institutions, in our case schools, not the child.

\section{Inclusive education}

The principle of inclusive education has emerged as a key area in education research and policy for well over two decades (e.g. Ainscow, Booth and Dyson 2006). The principle of inclusive education is advocated through organizations such as UN (UNESCO 2015), the World Bank (2017) and the European Commission (2018) in addition to a steadily growing research area in education and training. For instance, the yearly conference for the European Educational Research Association 2018 had the conference theme "Inclusion and exclusion, Resources for educational research". The global efforts towards an inclusive education can be traced back to the Salamanca Statement of 1994, a document ratified by 92 governments and 25 international organizations, addressing the rights to education for all. Following the Salamanca Statement, the international movement to promote inclusive education has been viewed as a reform of education and training, aiming to adapt education to pupils' diversity - in contrary to having children adapt to education (Hausstätter \& Jahnukainen 2014).

There is a broad consensus that inclusive education concerns increasing participation on several levels, such as culture, community and the mainstream curricula (Florian \& Black-Hawkins 2011), and that inclusion implies responding to the diversity within that classroom (Florian \& Linklater 2010). However, there is also a broad consensus that the interpretation of the term and the practice of it is not unified (e.g. Nilholm \& Göransson 2017). The ambiguous interpretation of the concept can be seen in the international research on the area where it is interpreted and conceptualized in a range of different ways (e.g. Dyson 2000; Kiuppis \& Hausstätter 2014; Nilholm \& Göransson 2017; Amor et al. 2018). It can be presented as a matter of placement, specifically concerning every child's right to education independent of the child's physical ability (e.g. Avramidis, Bayliss, \& Burden 2000; Croll \& Moses 2000), or in other ways concerned with specific disabilities and segregating/integrating methods (e.g. Antia, Stinson, \& Gausta 2001; Gilmore, Campbell, \& Cuskelly 2003). It can also be presented as a means for social justice, providing education to marginalized groups and effects on these efforts (e.g. Villa et al. 1996; Slee 2001), or it can present issues of democratic values as ways of education and training (e.g. Barton 1997). 
As we can see, inclusion is understood in a range of different ways, and the achievement of inclusive practices is still an ongoing challenge (Florian \& Spratt 2013). It also mainly concerns pupils with special needs (Hausstätter 2003; Nilholm \& Göransson 2017; Amor et al. 2018), even though the Salamanca Statement is advocating diversity as a quality. We would claim that if diversity is a quality, inclusive education should discuss diverse forms of education, not different attainment of the same education. However, a literature review of perspectives and trends in the research of the field (Amor et al. 2018) reports that other reviews mainly focus on "(...) exploring strategies and practices to improve academic knowledge and skills of students with SEN [special educational needs] in inclusive contexts" (p. 8). This could indicate that education for pupils with special needs, whether it is called inclusive education or not, is posing and solving questions in a quantitative manner, measuring and assessing according to the "normal" pupil. Thus, the educational strategy of a "negative education" is a paradox to the overarching aim of inclusive education. As long as we measure what the child is not able to do, we will not be working towards an inclusive education.

\section{A quantitative issue}

The early European special educational efforts towards individuals with disabilities were traditionally aimed at compensatory actions, specifically for children with sensory impairments or mental retardation. The educational efforts aimed at reducing the gap between the "abnormal" and the "normal" and these efforts were to a large extent anchored in a medical paradigmatic framework, using medical parameters (Skidmore 1996). This way of framing and understanding remediation of the disabled individual is referred to as the medical model. Within the medical model, biological and psychological abnormalities are examined, explained and resolved as an individual issue (Skidmore 1996). The disability is therefore understood as a biological and/or a psychological factor within the individual, explained and reasoned from the difficulties the individual experience. The methods of investigation have been measurements (Vygotsky 1993). Traditionally, special educational needs described within the medical model would suggest a remediation aiming to reduce the abnormality. For instance, a child with a hearing impairment would be trained to develop a functional language of speech (Kermit 2010). To be able to speak would be "normal" and the compensatory effort was to reduce the gap between the "abnormal" (no speech) and the "normal" (speech) (Kermit 2010). A child with a psychological disability would be examined with the psychological tool, the IQ-test. In Vygotsky's opinion, the psychometrical assessment of his time (IQ-tests) was merely concerned with collecting a statistic, quantitative amount of negative characteristics, insufficient to differentiate between biological disabilities and socially acquired disabilities (see Gindis 1995; Valsiner \& Van der Veer 1993). By using a quantitative measurement, the individual is assessed and habilitated in a relation to what is considered "normal". With these efforts, the intervention has set out to resolve the specific abnormality, or reducing it, and thereby normalize 
the situation for the child. The problems are thus "posed and resolved as quantitative problems" (Vygotsky 1993), measured according to a norm and subsequently remediated as an effort to reduce the difference between the norm and the actual ability. Vygotsky claims that this way of thinking has legitimized a basis of knowledge within the special educational field by using the quantitative language of cause and effect. Vygotsky (1993) describes this educational strategy as "negative education" because the starting point is a description of a person's deficiencies and limitations. Within this framework, the effect of the educational measures will be assessment according to certain normality criteria. In other words, the effect goal is also a "negative goal" which is based on a description of the deficiencies of the child you teach. Vygotsky (1993) contends that this leads to a reductionist pedagogy. Focusing on deficiencies, the consequence becomes an education aimed at reducing the negative.

\section{A qualitative issue}

Vygotsky suggests, however, that education for children with disabilities is a qualitative issue and not a quantitative.

A child whose development is impeded by a defect is not simply a child less developed than his peers; rather he has developed differently.... a child in each stage of his development, in each of his phases, represents a qualitative uniqueness, i.e., a specific organic and psychological structure; in precisely the same way a handicapped child represents a qualitatively different, unique type of development (Vygotsky 1993: 30).

His perspective emphasizes the fact that people with disabilities are qualitatively different and that one must meet this qualitative difference with qualitative different education. As we can see, his questioning and reasoning for educational differences is still not met in the literature for pupils with special needs, but it is still highly relevant.

Vygotsky's claim that knowledge of the development of the child with a defect cannot be built on the same foundation of knowledge as that of the "normal" child is still relevant, and he argues that the educational possibilities lie within the social motivation to "fit in". The development of children with and without defects follows different trajectories. For the child with a defect, the social implications of this defect may force the child to develop creative compensatory skills. Therefore, comparing skills and presuppositions with "the normal" will reduce the child's possibilities for development. The child with a disability will develop in a qualitative different way from the "normal" child and use other means to achieve a final goal. For instance, a blind child will compensate for his defect by developing "a psychological superstructure circumventing his impaired vision with only one goal in mind: to replace sight" (1993: 57). This would not have been an issue in a "blind world". The compensatory skills the child may develop are based on the social implications that he or she experiences by "being blind". This is also relevant for other defects; 
the child will try to overcome his defect and struggle "to be healthy and fully accepted socially" by strategically developing other skills. Vygotsky explains this organic relationship by Adler's theorization of the individual's ability to create balance. The child with a disability will develop compensatory skills or psychological functions in order to achieve equilibrium. So, when the child meets the society's expectations, these mechanisms will create a potential and a stimulus to compensate or overcompensate for the defect. While the defect, or impairment, might disable the child from certain activities, it can also be the source of the development of special features (1993: 34).

The problem with the reductionist point of view is that the educational institutions primarily compensate by reducing the gap. It does not take into consideration that the social institution is primarily facilitated for the "normal" child. Thus, when the child is facing social structures and expectations in educational institutions, his abilities will not be measured against the actual abilities, but against a constructed norm. Hence, a negative distance to the norm.

\section{Conclusion}

We claimed that the conception and rhetoric of pedagogy which Vygotsky questioned in his time are still relevant in the age of inclusive education. The educational system in several western countries is built upon the strategy of reducing the gap between the what the "normal" child can do and the expectations of the disabled child's competence and skills. When teaching children with disabilities, the educational system is constructed to handle the "normal" child, and will make adjustments for the disabled child in relation to what the "normal" child is capable of. This is in conflict with the ideology of inclusive education. In an international perspective, inclusive education is often viewed as a reform of education and training aiming to adapt education to students' diversity - in contrary to having children adapt to education. Even though inclusive education could be perceived in a narrow perspective to ensure the rights of students with disabilities, there is also a broader perspective, focusing of the substance of education and training. Thus, all pupils should also gain from education and training, both socially and academically. In our opinion, the educational strategy as a "negative education" is a paradox to the overarching aim of inclusive education. As long as we measure what the child is not able to do, we will not be working towards an inclusive education. Even though the research field of inclusive education seems to agree that inclusive education promote participation and diversity of all children, the focus of the majority of journal articles discuss issues of placement and academic skills, factors which can be perceived as crucial if the main goal is to do what the majority of pupils do.

Going back to the inclusive education, it is our opinion that Vygotsky's defectology might give us some leverage in achieving a more inclusive education for children with disabilities. Vygotsky's contribution in the field of special education was what he described as a "positive differential approach" (Vygotsky 1993: 122). That is the emphasis of identify- 
ing the disabled child from a point of strength rather than a disability (Vygotsky 1993). We argue that the theory of Vygotsky's defectology is of importance to the pedagogues' potential to recognise and identify the child's compensatory abilities. A positive differential approach to education for children with special needs will be a contribution to the field of inclusive education.

Inspired by Marxist-theory, Vygotsky was aware that education must be pointing forward and have goals. Education should ensure all people to find their optimal place as participants in a society. Hence, goals of education are not only to achieve academic skills, but to provide a basis for an inclusive society for all. Compensation is therefore not just a psychological phenomenon - one can also compensated by focusing on developing motoric and practical skills. Such skills can therefore be recognized as one way of developing compensating strategies in inclusive education.

Starting from a positive approach, children are seen an important source of information to the improvement of teaching and learning in inclusive environments. Therefore, an ongoing discussion moving forward a many-facetted understanding of what inclusive education is, and should be, crucial to confront the former paradigm seeing children as incomplete adults and disabilities as pathological problems.

\section{References}

Ainscow M., Booth T. \& Dyson A. (2006), Improving schools, developing inclusion. London, Routledge.

Amor A.M., Hagiwara M., Shogren K.A., Thompson J.R., Verdugo M.Á., Burke K.M. \& Aguayo V. (2018), International perspectives and trends in research on inclusive education: A systematic review. "International Journal of Inclusive Education", 1-19. doi: 10.1080/13603116.2018.1445304

Antia S.D., Stinson M.S. \& Gaustad M.G. (2002), Developing Membership in the Education of Deaf and Hard-of-Hearing Students in Inclusive Settings. "The Journal of Deaf Studies and Deaf Education", 7(3). doi: 10.1093/deafed/7.3.214

Avramidis E., Bayliss P. \& Burden R. (2000), Student teachers' attitudes towards the inclusion of children with special educational needs in the ordinary school. "Teaching and Teacher Education", 16(3). doi: https://doi.org/10.1016/S0742-051X(99)00062-1

Barton L. (1997), Inclusive education: romantic, subversive or realistic? "International Journal of Inclusive Education", 1(3).

Croll P. \& Moses D. (2000), Ideologies and utopias: education professionals'views of inclusion. "European Journal of Special Needs Education", 15(1). doi: 10.1080/088562500361664

Davydov V.V. (1995), The influence of LS Vygotsky on education theory, research, and practice. "Educational Researcher", 24(3).

Dyson A. (2000), Inclusion \& inclusions: Theories and discourses in inclusive education. In: H. Daniels \& P. Garner (Eds.), Inclusive Education. Supporting Inclusion in Educational Systems. London, Kogan Page Limited.

European Commission. (2018), Education. Hentet fra https://ec.europa.eu/europeaid/sectors/human-development/education_en 
Florian L. \& Black-Hawkins K. (2011), Exploring inclusive pedagogy. "British Educational Research Journal", 37(5).

Florian, L. \& Linklater, H. (2010), Preparing teachers for inclusive education: using inclusive pedagogy to enhance teaching and learning for all. "Cambridge Journal of Education", 40(4). doi: 10.1080/0305764X.2010.526588

Florian L. \& Spratt J. (2013), Enacting inclusion: a framework for interrogating inclusive practice. "European Journal of Special Needs Education”, 28(2). doi: 10.1080/08856257.2013.778111

Gilmore L., Campbell J. \& Cuskelly M. (2003), Developmental Expectations, Personality Stereotypes, and Attitudes Towards Inclusive Education: Community and teacher views of Down syndrome. "International Journal of Disability, Development and Education", 50(1). doi: 10.1080/1034912032000053340

Gindis B. (1995), The social/cultural implication of disability: Vygotsky's paradigm for special education. "Educational Psychologist", 30(2).

Gindis B. (1999), Vygotsky's Vision: Reshaping the Practice of Special Education for the 21st Century. "Remedial and Special Education", 20(6). doi: 10.1177/074193259902000606

Hausstätter R.S. \& Jahnukainen M. (2014), From integration to inclusion and the role of special education. In: F. Kiuppis \& R.S. Hausstätter (Eds.), Inclusive education twenty years after Salamanca. New York, Peter Lang.

Kermit P.S. (2010), Etikk og audiopedagogikk - en drøfting på bagrunn av et historisk eksempel [Ethics and audio pedagogy - a discussion from a historical example]. In: S.M. Reindal \& R. Hausstätter (Eds.), Spesialpedagogikk og etikk. Kollektivt ansvar og individuelle rettigheter [Special pedagogy and ethics: Collective responsibility and individual rights]. Oslo, Cappelen Damm Høyskoleforlaget.

Kozulin A. \& Gindis B. (2007), Sociocultural Theory and Education of Children with Special Needs: From Defectology to Remedial Pedagogy. In: H. Daniels, J.V. Wertsch, \& M. Cole (Eds.), The Cambridge Companion to Vygotsky. Cambridge: Cambridge University Press. (Hentet fra https://www.cambridge.org/core/books/cambridge-companion-to-vygotsky/sociocultural-theory-and-education-of-children-with-special-needs-from-defectology-to-remedial-pedagogy/ E9395CCAB4F8AB9FC10D8EE9E404CAFB).

Nilholm C. \& Göransson K. (2017), What is meant by inclusion? An analysis of European and North American journal articles with high impact. "European Journal of Special Needs Education", 32(3). doi: 10.1080/08856257.2017.1295638

Skidmore D. (1996), Towards an integrated theoretical framework for research into special educational needs. "European Journal of Special Needs Education", 11(1). doi: $10.1080 / 0885625960110103$

Slee R. (2001), Social justice and the changing directions in educational research: The case of inclusive education. "International Journal of Inclusive Education", 5(2-3).

Smagorinsky P. (2012), Vygotsky, "defectology," and the inclusion of people of difference in the broader cultural stream. "Journal of Language and Literacy Education", 8(1).

UNESCO (1994), The Salamanca Statement and Framework for action on special needs education: Adopted by the World Conference on Special Needs Education; Access and Quality. Salamanca, Spain, 7-10 June 1994. Hentet fra http://www.unesco.org/education/pdf/SALAMA_E.PDF

UNESCO. (2015). Ten questions on inclusive education. Hentet fra http://www.unesco.org/new/ en/education/themes/strengthening-education-systems/inclusive-education/10-questions-oninclusive-quality-education/ 
Valsiner J. \& Veer R.V. d. (1993), The encoding of distance: The concept of the zone of proximal development and its interpretations. In: R.R. Cocking \& K.A. Renninger (Eds.), The development and meaning of psychological distance. New Jersey, Erlbaum.

Vaughn S., Elbaum B.E. \& Schumm J.S. (1996), The effects of inclusion on the social functioning of students with learning disabilities. "Journal of Learning Disabilities", 29(6).

Villa R.A., Thousand J.S., Meyers H., \& Nevin A. (1996), Teacher and administrator perceptions of heterogeneous education. "Exceptional Children", 63(1).

Vygotsky L.S. (1987), The collected works of LS Vygotsky, Vol 1: Problems of general psychology. New York, Plenum.

Vygotsky L.S. (1993), The collected works of LS Vygotsky, Vol 2: The fundamentals of defectology. New York, Plenum.

Vygotsky L.S. (1998), The collected works of LS Vygotsky, Vol 5: Child psychology. New York, Plenum.

World Bank (2017), 'Learning for All' Must Include Children with Disabilities. Hentet fra https:// www.worldbank.org/en/news/feature/2017/11/30/learning-for-all-must-include-children-withdisabilities 